\title{
Depth-wise fractionation of sulphur in cultivated soils of low and mid hills of Himachal Pradesh
}

\author{
Suri, D. ${ }^{1}$, , Sharma, V.K. ${ }^{2}$, Upadhyay, R.G. ${ }^{3}$, Anjali ${ }^{4}$, Nazir, G. ${ }^{5}$, Ankit $^{6}$
}

Received: 08.04.2021

Revised: 18.05.2021

Accepted: 28.05.2021

\begin{abstract}
The current investigation was conducted to study the fractions of sulphur in nine districts of low and mid hills of Himachal Pradesh. For this purpose 31 representative soil sampling sites were selected from nine districts and the soil samples were analyzed for physicochemical properties and different fractions of sulphur (water soluble sulphur, exchangeable sulphur, available sulphur, non-sulphate sulphur, organic sulphur and total sulphur). The results indicated that the total sulphur in soils varied from 98.2 to $470.1 \mathrm{mg} \mathrm{kg}^{-1}$ in surface soil $(0-15 \mathrm{~cm})$ and 67.2 to $370.7 \mathrm{mg} \mathrm{kg}^{-1}$ in subsurface layer $(15-60 \mathrm{~cm})$. The organic sulphur varied from 80.5 to $401.1 \mathrm{mg} \mathrm{kg}^{-1}$ in surface and 44 to $306.1 \mathrm{mg} \mathrm{kg}^{-1}$ in subsurface layer. The water soluble sulphur, exchangeable sulphur, available sulphur and non-sulphate sulphur varied from 1.7 to $9.2,2.7$ to $18.4,4.5$ to 27.6 and 10.2 to $58.9 \mathrm{mg} \mathrm{kg}^{-1}$ respectively in surface soil and 0.5 to $5.4,1$ to $17.7,3.7$ to 23.5 and 12.5 to $50.2 \mathrm{mg} \mathrm{kg}^{-1}$, respectively in sub-surface soil. It was observed during course of study that with increase in the soil depth the content of different fractions of sulphur decreased. These soils had the major part of their total sulphur content in organic form followed by non-sulphate sulphur, available sulphur, exchangeable sulphur and water soluble sulphur. It can be concluded that the soil texture and organic carbon content played a major role in determining the quantity of different fractions of sulphur in these soils.
\end{abstract}

Key words: Available sulphur, Exchangeable sulphur, Non-sulphate sulphur, Organic sulphur, Total sulphur, Water soluble sulphur

\section{Introduction}

Sulphur is one among the seventeen essential elements and the fourth most important nutrient for crop production after N, P and $\mathrm{K}$. The sulphur deficiency is widespread in Indian soils and it has been emerging as major limitation in sustaining crop production and productivity. Intensive cultivation with high yielding varieties of crops and application of high rates of fertilizers devoid of secondary nutrients resulted in deficiency of secondary nutrients especially sulphur reserve of soil at a faster rate. Not surprisingly, sulphur in soils occurs in different forms such as water soluble, exchangeable, available, non-sulphate, organic and total sulphur. The availability of sulphur in a soil is not only altered by exist in dynamic equilibrium in soil (Azmi et al., 2018).

\section{Author's Address}

Department of Soil Science, Chaudhary Sarvan Kumar Himachal Pradesh Krishi Vishvavidyalaya, Palampur, Himachal Pradesh 176062

E-mail.: suri.deepika1993@gmail.com
For this reason, the understanding of management practices but also depends upon various forms of sulphur present as these different forms of sulphur different forms of sulphur in soils and their depth- wise distribution helps in keeping a watch on sulphur nutrition of crops. Such information in low and mid hills of Himachal Pradesh is very mearge. Therefore, this investigation was planned for depth-wise characterization of sulphur and their interrelationship with soil characterstics in low and mid hills of Himachal Pradesh.

\section{Materials and Methods}

In the current study, 31 sampling sites were selected to represent the cultivated soils of low and mid hills of Himachal Pradesh. These sites represent the soils under maize-wheat, paddywheat, vegetables, tea gardens and orchards. The soil profile samples (at $0-15 \mathrm{~cm}, 15-30 \mathrm{~cm}$ and $30-60 \mathrm{~cm}$ depth ) were collected from Kangra, 
Una, Sirmour, Solan, Hamirpur, Mandi, Kullu, Bilaspur and Chamba districts and were analysed for physicochemical properties using standard methods (Jackson 1973). In order to study the depth-wise distribution of sulphur, these soil samples were analysed for different forms of sulphur. Total and organic sulphur were determined as per methods outlined by Chapman and Pratt (1961) and Bradsley and Lancaster (1965), respectively. Water soluble sulphur was estimated by extracting the soil with de-ionized water. Exchangeable sulphur was estimated by substraction of water soluble sulphur from available sulphur. Available sulphur was extracted with $0.15 \%$ Calcium chloride solution (Williams and Steinsbergs 1959). The sulphur in all these extracts was estimated turbidimetrically (Chesnin and Yein 1951). The difference between organic sulphur plus available sulphur contents and total sulphur was denoted as nonsulphate sulphur.

\section{Results and Discussion}

Soil $\mathrm{pH}$, Electrical conductivity $(\mu \mathrm{S} / \mathrm{cm})$, Organic carbon $(\mathrm{g} / \mathrm{kg})$, sand $(\%)$, silt $(\%)$, clay $(\%)$, Cation exchange capacity $\left(\mathrm{cmol}\left(\mathrm{p}^{+}\right) / \mathrm{kg}\right)$ Base saturation (\%) and Calcium carbonate (\%) in low hill zone varied from 6.2 to $7.8,150$ to $290,3.7$ to $11.7,47$ to 80,12 to 35,8 to 18,5 to $10.6,60$ to 74 and 0.30 to 2.15 in surface soils and from 6.3 to $7.9,170$ to $300,0.9$ to $9.8,46$ to 81,13 to 35,6 to $19,3.4$ to $10.4,61$ to 75 and 0.34 to 2.36 in subsurface soils, respectively. In mid hill zone soil $\mathrm{pH}$, Electrical conductivity $(\mu \mathrm{S} / \mathrm{cm})$, Organic carbon $(\mathrm{g} / \mathrm{kg})$, sand $(\%)$, silt $(\%)$, clay $(\%)$,Cation exchange capacity $\left(\mathrm{cmol}\left(\mathrm{p}^{+}\right) / \mathrm{kg}\right)$ Base saturation $(\%)$ and Calcium carbonate (\%) varied from 5.4 to $6.8,50$ to $250,3.4$ to 20,25 to 75,12 to 43,11 to $32,6.9$ to $16.4,50$ to 71 and 0.13 to 1.28 in surface soils and from 5.5 to $6.8,90$ to $290,1.1$ to $8.6,26$ to 76,13 to 43,10 to $31,4.5$ to $15.2,51$ to 72 and 0.14 to 1.31 in subsurface soils, respectively.

Irrespective of the land use, organic carbon and cation exchange capacity decreased with increasing soil depth, soil $\mathrm{pH}, \mathrm{EC}$, and base saturation increased with increasing depth whereas other properties namely sand, silt and clay exhibited an irregular trend of distribution with soil depth. Water soluble, exchangeable, available, organic, non-sulphate and total sulphur in low hills varied from 1.7 to $6.6,2.7$ to 10.4 , 4.5 to $16.5,82.2$ to $240.5,10.2$ to 25.5 and 98.2 to 281.9 in surface soils and from 0.5 to $4.4,2.9$ to $12,3.7$ to $15.8,44$ to $189.4,12.5$ to 29.8 and 67.2 to 230.1 in subsurface soils, respectively (Table 1).

In mid hills water soluble, exchangeable, available, organic, non-sulphate and total sulphur varied from 1.8 to $9.2,3.7$ to $18.4,5.5$ to 27.6 , 80.5 to $401.1,19.5$ to 58.9 and 106.8 to 470.1 in surface soils and from 0.7 to $5.4,1$ to $17.7,4.7$ to $23.5,58.1$ to $306.1,17.8$ to 50.2 and 86.6 to 370.7 in subsurface soils, respectively (Table 2 ).

In the present study it was concluded that content of all forms of sulphur decreased with an increase in soil depth (Table 1\&2). These had the tendency to get concentrated in upper layer and thereafter it decreases with increase in soil depth. It may be explained on the basis of decrease in organic carbon and clay content with depth. The nature and amount of soil organic matter, besides climate/altitude and soil texture, largely determined the content of sulphur fractions and their distribution pattern in soil profiles. These results were in agreement with the findings of Tripathi et al. (1997), Trivedi el al. (2000), Parkash et al. (2003) and Mondal (2016).

\section{Conclusion}

These soils of low and mid hills of Himachal Pradesh had the major part of their total sulphur content in organic form followed by nonsulphate, available, exchangeable and water soluble sulphur. It can be concluded that organic carbon, $\mathrm{pH}$ and clay content are the three important controlling factors of different forms of sulphur. Being the most important and widely measured fraction 'available sulphur' is mainly controlled by total sulphur and organic sulphur. And among the different fractions of sulphur, the organic sulphur is the dominant fraction irrespective of the soil type. 
Depth-wise fractionation of sulphur in cultivated soils

Table 1. Vertical distribution of different sulphur fractions $(\mathrm{mg} / \mathrm{kg})$ in representative soils of low hills

\begin{tabular}{|c|c|c|c|c|c|c|c|c|c|}
\hline SN & Site & Land use type & $\begin{array}{l}\begin{array}{l}\text { Depth } \\
\text { (cm) }\end{array} \\
\end{array}$ & WS-S & Ex-S & Av-S & Org-S & NS-S & Total-S \\
\hline & \multicolumn{9}{|c|}{$\begin{array}{c}\text { Entisols } \\
\end{array}$} \\
\hline \multirow[t]{3}{*}{1} & Sugal & Maize-wheat & $0-15$ & 4.3 & 7.3 & 11.6 & 159.4 & 20.8 & 192.4 \\
\hline & & & $15-30$ & 2.7 & 7.2 & 10.3 & $117 . .1$ & 19.2 & 148.6 \\
\hline & & & $30-60$ & 1.1 & 5.8 & 8.9 & 79.7 & 17.6 & 110.2 \\
\hline \multirow[t]{3}{*}{2} & SidhChalehr & Maize-wheat & $0-15$ & 1.7 & 2.8 & 4.5 & 86.5 & 19.9 & 110.9 \\
\hline & & & $15-30$ & 1.0 & 1.9 & 3.9 & 72.2 & 18.2 & 96.3 \\
\hline & & & $30-60$ & 0.7 & 0.9 & 3.7 & 53.9 & 16.3 & 79.9 \\
\hline \multirow[t]{3}{*}{3} & Naggal & Paddy-wheat & $0-15$ & 5.7 & 10.3 & 16 & 203.9 & 24.1 & 244.1 \\
\hline & & & $15-30$ & 4.2 & 9.6 & 14.8 & 144.1 & 23.9 & 184.8 \\
\hline & & & $30-60$ & 2.9 & 7.8 & 13.7 & 100.0 & 20.1 & 140.8 \\
\hline \multirow[t]{3}{*}{4} & Fatehpur-I & Vegetables & $0-15$ & 2.2 & 3.6 & 5.8 & 82.2 & 10.2 & 98.2 \\
\hline & & & $15-30$ & 1.1 & 2.7 & 4.8 & 57.2 & 9.5 & 74.5 \\
\hline & & & $30-60$ & 0.5 & 1.8 & 4.3 & 51.1 & 7.7 & 69.1 \\
\hline \multirow[t]{3}{*}{5} & Gharjarot & Vegetables & $0-15$ & 6.1 & 10.4 & 16.5 & 220.5 & 25.5 & 262.5 \\
\hline & & & $15-30$ & 4.3 & 9.5 & 15.8 & 169.5 & 23.4 & 212.7 \\
\hline & & & $30-60$ & 2.9 & 7.4 & 14.9 & 153.7 & 20.8 & 198.4 \\
\hline \multirow[t]{3}{*}{6} & Jankaur-III & Sugarcane & $0-15$ & 3.3 & 5.2 & 8.5 & 124.5 & 18.5 & 151.5 \\
\hline & & & $15-30$ & 2.1 & 5.0 & 7.6 & 95.6 & 17.9 & 123.1 \\
\hline & & & $30-60$ & 1.1 & 3.7 & 6.8 & 71.6 & 15.2 & 99.6 \\
\hline \multirow[t]{3}{*}{7} & Sarsan & Sugarcane & $0-15$ & 3.0 & 5.0 & 8.0 & 111.0 & 21.7 & 140.7 \\
\hline & & & $15-30$ & 1.8 & 4.7 & 7.5 & 82.7 & 21.6 & 113.8 \\
\hline & & & $30-60$ & 1.0 & 2.8 & 6.8 & 70.7 & 19.4 & 101.9 \\
\hline \multirow[t]{2}{*}{8} & Indpur-I & Orchards & $0-30$ & 1.8 & 2.7 & 4.5 & 84.5 & 17.0 & 106.0 \\
\hline & & & $30-60$ & 0.7 & 2.0 & 3.7 & 44.0 & 15.5 & 67.2 \\
\hline \multirow[t]{3}{*}{9} & Panjahra-II & Orchards & $0-30$ & 3.9 & 6.4 & 10.3 & 157.7 & 23.4 & 191.4 \\
\hline & & & $30-60$ & 1.1 & 4.4 & 8.5 & 87.8 & 20.2 & 121.5 \\
\hline & \multicolumn{9}{|c|}{ Inceptisols } \\
\hline \multirow[t]{3}{*}{10} & Beli Diawar & Maize-wheat & $0-15$ & 6.6 & 9.9 & 16.5 & 222.5 & 21.9 & 260.9 \\
\hline & & & $15-30$ & 4.1 & 8.6 & 14.7 & 183.5 & 20.5 & 220.7 \\
\hline & & & $30-60$ & 2.2 & 6.7 & 12.9 & 162.1 & 18.2 & 199.2 \\
\hline \multirow[t]{3}{*}{11} & Har & Maize-wheat & $0-15$ & 2.7 & 4.4 & 7.1 & 110.9 & 23.9 & 141.9 \\
\hline & & & $15-30$ & 1.6 & 3.6 & 6.2 & 88.4 & 22.1 & 119.7 \\
\hline & & & $30-60$ & 1.2 & 1.7 & 5.9 & 61.9 & 18.4 & 94.2 \\
\hline \multirow[t]{3}{*}{12} & $\begin{array}{l}\text { Rampur } \\
\text { Bharapur }\end{array}$ & Paddy-wheat & $0-15$ & 3.7 & 5.7 & 9.4 & 134.6 & 18.2 & 162.2 \\
\hline & & & $15-30$ & 2.3 & 4.9 & 8.2 & 96.1 & 17.5 & 123.8 \\
\hline & & & $30-60$ & 1.1 & 2.2 & 7.3 & 74.1 & 15.3 & 102.7 \\
\hline \multirow[t]{3}{*}{13} & Khajurna & Vegetables & $0-15$ & 6.3 & 10.2 & 16.5 & 240.5 & 24.9 & 281.9 \\
\hline & & & $15-30$ & 4.4 & 9.5 & 14.9 & 189.4 & 23.8 & 230.1 \\
\hline & & & $30-60$ & 1.9 & 7.9 & 13.8 & 164.5 & 20.1 & 205.4 \\
\hline \multirow[t]{3}{*}{14} & Kotli Byas & Sugarcane & $0-15$ & 3.8 & 6.0 & 9.8 & 153.2 & 20.6 & 183.6 \\
\hline & & & $15-30$ & 2.5 & 5.2 & 8.7 & 106.8 & 19.7 & 137.2 \\
\hline & & & $30-60$ & 1.0 & 4.3 & 7.3 & 83.0 & 17.8 & 114.1 \\
\hline \multirow[t]{2}{*}{15} & Kalera & Orchards & $0-30$ & 2.7 & 4.0 & 6.7 & 110.3 & 21.6 & 138.6 \\
\hline & & & $30-60$ & 1.0 & 2.1 & 5.1 & 57.9 & 20.4 & 87.4 \\
\hline \multicolumn{4}{|c|}{ Mean \pm SD (surface soils) } & $\begin{array}{c}3.9 \\
\pm 1.6\end{array}$ & $\begin{array}{c}6.3 \\
\pm 2.8\end{array}$ & $\begin{array}{l}10.1 \\
\pm 4.4\end{array}$ & $\begin{array}{r}146.8 \\
\pm 53.3\end{array}$ & $\begin{array}{l}20.8 \\
\pm 3.9\end{array}$ & $\begin{array}{l}177.8 \\
\pm 60.3\end{array}$ \\
\hline \multicolumn{4}{|c|}{ Mean \pm SD (Sub - surface soils) } & $\begin{array}{c}1.9 \\
\pm 1.2 \\
\end{array}$ & $\begin{array}{c}4.9 \\
\pm 2.7 \\
\end{array}$ & $\begin{array}{c}8.9 \\
\pm 4.0 \\
\end{array}$ & $\begin{array}{l}100.7 \\
\pm 43.9 \\
\end{array}$ & $\begin{array}{l}18.5 \\
\pm 3.7 \\
\end{array}$ & $\begin{array}{l}132.5 \\
\pm 49.9 \\
\end{array}$ \\
\hline
\end{tabular}


Suri et al.

Table 2: Vertical distribution of different sulphur fractions $(\mathrm{mg} / \mathrm{kg})$ in representative soils of mid hills

\begin{tabular}{|c|c|c|c|c|c|c|c|c|c|}
\hline SN & Site & Land use type & Depth (cm) & WS-S & Ex-S & Av-S & Org-S & NS-S & Total-S \\
\hline & \multicolumn{9}{|c|}{ Entisols } \\
\hline \multirow[t]{3}{*}{1} & Panjla & Maize-wheat & $0-15$ & 2.0 & 4.4 & 6.4 & 80.5 & 19.9 & 106.8 \\
\hline & & & $15-30$ & 1.2 & 4.1 & 5.8 & 69.9 & 20.5 & 97.2 \\
\hline & & & $30-60$ & 0.9 & 2.8 & 5.7 & 58.3 & 18.3 & 87.3 \\
\hline \multirow[t]{3}{*}{2} & Sukrayin & Maize-wheat & $0-15$ & 4.9 & 10.4 & 15.3 & 186.3 & 45.1 & 246.7 \\
\hline & & & $15-30$ & 2.3 & 9.8 & 14.1 & 148.8 & 43.3 & 210.2 \\
\hline & & & $30-60$ & 1.2 & 7.1 & 13.3 & 117.2 & 41.7 & 179.2 \\
\hline \multirow[t]{3}{*}{3} & Bsal & Paddy-wheat & $0-15$ & 1.8 & 3.7 & 5.5 & 94.5 & 19.5 & 119.5 \\
\hline & & & $15-30$ & 1.1 & 2.9 & 5.0 & 73.0 & 18.2 & 99.2 \\
\hline & & & $30-60$ & 0.7 & 1.0 & 4.7 & 58.1 & 17.8 & 86.6 \\
\hline \multirow[t]{3}{*}{4} & Deor & Vegetables & $0-15$ & 4.9 & 10.4 & 15.3 & 199.7 & 21.2 & 236.2 \\
\hline & & & $15-30$ & 3.1 & 9.6 & 13.7 & 176.1 & 20.3 & 212.1 \\
\hline & & & $30-60$ & 1.3 & 6.9 & 12.2 & 156.5 & 19.5 & 193.2 \\
\hline \multirow[t]{3}{*}{5} & Duwara & Vegetables & $0-15$ & 9.2 & 18.4 & 27.6 & 375.4 & 41.5 & 444.5 \\
\hline & & & $15-30$ & 4.8 & 17.7 & 23.5 & 303.5 & 40.2 & 370.2 \\
\hline & & & $30-60$ & 2.8 & 15.0 & 21.8 & 246.2 & 38.2 & 314.2 \\
\hline \multirow[t]{2}{*}{6} & Jia & Orchards & $0-30$ & 4.5 & 10.0 & 14.5 & 298.2 & 23.5 & 336.2 \\
\hline & & & $30-60$ & 1.4 & 8.2 & 12.6 & 276.5 & 22.7 & 318.8 \\
\hline \multirow[t]{3}{*}{7} & Drabad & Orchards & $0-30$ & 6.9 & 13.4 & 20.3 & 296.7 & 58.9 & 375.9 \\
\hline & & & $30-60$ & 2.5 & 12.9 & 19.4 & 189.7 & 50.2 & 270.3 \\
\hline & \multicolumn{9}{|c|}{ Inceptisols } \\
\hline \multirow[t]{3}{*}{8} & Dun & Maize-wheat & $0-15$ & 3.9 & 7.6 & 11.5 & 158.7 & 46.9 & 217.1 \\
\hline & & & $15-30$ & 2.5 & 6.2 & 10.7 & 121.4 & 44.4 & 180.5 \\
\hline & & & $30-60$ & 1.2 & 5.4 & 9.6 & 106.4 & 41.2 & 167.2 \\
\hline \multirow[t]{3}{*}{9} & $\begin{array}{l}\text { Sambar-8- } \\
\text { mile }\end{array}$ & Maize-wheat & $0-15$ & 4.8 & 10.5 & 15.3 & 240.9 & 21.3 & 277.5 \\
\hline & & & $15-30$ & 3.2 & 9.2 & 14.4 & 192.3 & 20.5 & 230.2 \\
\hline & & & $30-60$ & 1.1 & 7.4 & 12.5 & 129.7 & 18.5 & 168.7 \\
\hline \multirow[t]{3}{*}{10} & Sutiara & Paddy-wheat & $0-15$ & 3.5 & 6.8 & 10.3 & 163.6 & 46.2 & 220.1 \\
\hline & & & $15-30$ & 1.7 & 6.0 & 8.7 & 134.3 & 44.3 & 190.3 \\
\hline & & & $30-60$ & 1.0 & 4.2 & 8.2 & 99.0 & 40.3 & 158.5 \\
\hline \multirow[t]{3}{*}{11} & $\begin{array}{c}\text { Bharatkoo } \\
\mathrm{p} \\
\end{array}$ & Vegetables & $0-15$ & 6.4 & 14.6 & 21.0 & 351.0 & 40.2 & 412.2 \\
\hline & & & $15-30$ & 5.4 & 13.9 & 20.3 & 306.1 & 42.3 & 370.7 \\
\hline & & & $30-60$ & 3.7 & 11.2 & 18.9 & 134.6 & 40.3 & 202.8 \\
\hline \multirow[t]{2}{*}{12} & Tarked & Tea gardens & $0-30$ & 5.9 & 14 & 19.9 & 397.8 & 45.7 & 463.4 \\
\hline & & & $30-60$ & 1.2 & 12.3 & 16.5 & 223.9 & 41.2 & 290.6 \\
\hline \multirow[t]{3}{*}{13} & Bhuntar & Orchards & $0-30$ & 4.3 & 9.9 & 14.2 & 236.8 & 21.8 & 272.8 \\
\hline & & & $30-60$ & 1.4 & 8.4 & 11.8 & 153.4 & 19.5 & 189.7 \\
\hline & \multicolumn{9}{|c|}{ Alfisols } \\
\hline \multirow[t]{3}{*}{14} & Kroth & Paddy-wheat & $0-15$ & 3.3 & 6.9 & 10.2 & 134.9 & 41.9 & 187.0 \\
\hline & & & $15-30$ & 2.4 & 5.2 & 9.6 & 123.4 & 40.5 & 176.5 \\
\hline & & & $30-60$ & 1.1 & 4.8 & 8.9 & 104.9 & 39.8 & 160.6 \\
\hline \multirow[t]{2}{*}{15} & Taragarh & Tea gardens & $0-30$ & 7.7 & 15.4 & 23.1 & 309.4 & 22.6 & 355.1 \\
\hline & & & $30-60$ & 3.4 & 12.2 & 20.6 & 202.7 & 19.3 & 250.6 \\
\hline \multirow[t]{2}{*}{16} & Sungal & Tea gardens & $0-30$ & 7.1 & 15.5 & 22.6 & 401.1 & 46.4 & 470.1 \\
\hline & & & $30-60$ & 1.4 & 13.9 & 19.3 & 211.8 & 42.7 & 283.8 \\
\hline \multicolumn{4}{|c|}{ Mean \pm SD (surface soils) } & $\begin{array}{c}5.1 \\
\pm 2.0 \\
\end{array}$ & $\begin{array}{r}10.7 \\
\pm 4.2 \\
\end{array}$ & $\begin{array}{r}15.8 \\
\pm 6.2 \\
\end{array}$ & $\begin{array}{c}245.3 \\
\pm 105.5 \\
\end{array}$ & $\begin{array}{l}35.2 \\
\pm 3.2 \\
\end{array}$ & $\begin{array}{c}296.3 \\
\pm 116.4 \\
\end{array}$ \\
\hline & Mean & D (Sub - surface & ls) & $\begin{array}{c}2.1 \\
\pm 1.2 \\
\end{array}$ & $\begin{array}{c}8.4 \\
\pm 4.2 \\
\end{array}$ & $\begin{array}{l}13.1 \\
\pm 5.5\end{array}$ & $\begin{array}{r}158.4 \\
\pm 71.2 \\
\end{array}$ & $\begin{array}{c}32.5 \\
\pm 11.6 \\
\end{array}$ & $\begin{array}{r}209.9 \\
\pm 79.9 \\
\end{array}$ \\
\hline
\end{tabular}


Depth-wise fractionation of sulphur in cultivated soils

\section{References}

Azmi, N. Y., Seema and Manish, K. 2018. New technique for sequential fractionation of soil sulphur. International Journal of Current Microbiology and Appled Sciences, 7: 3397-3405.

Bardsley, L. E. and Lancaster, J. D. 1965. Determination of reserve sulphur and soluble sulphates in soil. Soil Science Society of America Proceedings, 24:265.

Chapman, H. D. and Pratt, P. F. 1961. Methods of Analysis for soils, plants and water. University of California, Berkeley, CA, USA, pp. 150-179.

Chesnin, L. and Yien, C. H. 1951. Turbidimetric determination of available sulphate. Soil Science Society of America Proceedings, 15:149-151.

Jackson, M.L. 1973. Soil Chemical Analysis. Prentise Hall of India Pvt. Ltd., New Delhi, pp. 111-272.

Mondal, K. 2016. Vertical distribution of different forms of soil sulphur in some soils of North-eastern region of Haryana, India. International Journal of Ecology and Environmental Sciences, 42: 349-355.
Parkash, O., Malik, R. S., Singh, K., Narwal, R. P. and Ramkala. 2003. Depthwise distribution of sulphur in some paddy soils of Haryana, India. Indian Journal of Agricultural Research, 37:76-78.

Tripathi, K., Singh, K. and Karwasra, S. P. S. 1997. Forms of sulphur and their distribution in some Aridisols of Haryana state under grape vineyards. Journal of the Indian Society of Soil Science, 45:386-88.

Trivedi, S. K., Bansal, K. N., Tomar, R. A. S. and Verma, R. S. 2000. Vertical distribution of forms of sulphur in some profiles of Morena and Bhind Districts of Madhya Pradesh. Journal of the Indian Society of Soil Science, 48:238-24.

Williams, C. H. and Steinbergs, A. 1959. Soil sulphur fractions as chemical indices of available $\mathrm{S}$ in some Australian soils. Australian Journal of Agricultural Research, 10:349-352.

Xiao, H., Li, N. and Liu, C. 2015. Source identification of sulfur in uncultivated surface soils from four Chinese provinces. Pedosphere, 25:140-149. 